\title{
FRATERNIDADE NA POLÍTICA
}

Por Iracema Amaral, tradução para o Português do Brasil do original: LUBICH, Chiara. Fraternità in Politica, 2002.

Senhor presidente do Parlamento, autoridades políticas,

Hoje devo expor-lhes um assunto, aparentemente genérico e particular, porém de grande e extrema atualidade: a fraternidade. Os dolorosos acontecimentos terroristas de ontem, no Quênia, reforçou, no coração de muitos uma convicção: estamos realmente num período singular, que poderia ser definido "pós 11 de setembro de 2001". Isso é confirmado por outros atos terroristas, como aquele de ontem. É um período de angústia e de medo, sem dúvida. Mas, uma vez que, no coração do homem, e também no nosso, a esperança é a última que morre, perguntamo-nos: A nossa reação deve ser somente de medo, de vingança? Devemos ter só propósitos de guerra? No nosso tempo, não existe algum sinal que deixe espaço para algo menos trágico, mais positivo, para uma visão menos negativa do presente e do futuro?

Provavelmente sim. Eu, e também outras pessoas, não posso me esquecer, por exemplo, do que aconteceu em Nova York, logo depois dos atentados às Torres. É claro que o abatimento era infinito nos Estados Unidos e em outras partes. Mas logo a seguir se deu um fato incomum. Nova York transformou-se. Daquela montanha de sofrimento, daquela noite repentina em pleno dia, despontou uma competição de solidariedade jamais vista: os muros da indiferença se desfizeram numa avalanche de ajudas concretas, de conforto, de disposição em agir para aliviar o sofrimento das pessoas.

Os Estados Unidos são um país multirreligioso, multiétnico, multicultural e ofereceram ao mundo, numa de suas cidades, um exemplo de solidariedade, de unidade. É como se os olhos de um povo se abrissem para enxergar a necessidade absoluta de que se instaure - a fraternidade - e não só entre os americanos.

Esta exigência foi enfatizada com extrema urgência nos meses sucessivos, quando foram expostas as várias e eventuais causas do terrorismo. Entre elas, como todos sabem, a fundamental é o desequilíbrio, no nosso planeta, entre países pobres e ricos. Esse desequilíbrio reivindica maior partilha de bens. E isso não será possível enquanto a humanidade não se considerar uma única família, enquanto ela não for invadida por um ardente desejo e por um forte esforço de realizar a fraternidade. 
A fraternidade universal não é uma ideia de hoje. Já foi a aspiração de espíritos fortes como o Mahatma Gandhi, Martin Luther King, o Dalai Lama.

Mas quem indicou e trouxe a fraternidade, como dom essencial para humanidade, foi Jesus. Ele rezou assim antes de morrer: «Pai, que todos sejam um» (Cf Jo 17,21). Revelando que Deus é Pai e que os homens, por isso, são todos irmãos, Jesus introduz a ideia da humanidade como "uma família". E, com isso, abate os muros que separam os "iguais" dos "diferentes", os amigos dos inimigos. E livra cada homem das amarras que o prendem, das mil e uma formas de subordinação e de escravidão, realizando, assim, uma autêntica revolução existencial, cultural e política.

Desse modo, a ideia da fraternidade começou a penetrar na história. E todos são chamados, a construí-la inclusive aqueles que trabalham na política. Foi o que disse, por exemplo, a Revolução Francesa que, com o seu lema: «Liberdade, igualdade, fraternidade», sintetizou o grande projeto político da modernidade, embora a sua interpretação desse projeto seja muito redutiva. Além disso, ainda que numerosos países, instaurando regimes democráticos, tenham conseguido, de certo modo, realizar a liberdade e a igualdade, a fraternidade permaneceu mais na teoria do que na prática.

"A lição do século vinte - foi dito - é que, para termos um futuro mais humano, é preciso passar pela aceitação do trinômio bíblico: liberdade, igualdade, fraternidade, que deve ser purificado das ideologias e conduzido a escutar o homem (...) descoberto como co-humanidade. (...) O elemento básico do trinômio, no plano da garantia vital, é a fraternidade"'.

Embora os conflitos, ainda presentes no nosso planeta, pareçam afirmar o contrário, ainda que as previsões negativas deixem o homem moderno com o coração em ânsia, não podemos negar que o mundo hoje tende para a unidade, aliás, para a unidade global, universal. É um sinal dos tempos e muitos fatores religiosos, sociais e políticos estão demonstrando. Podemos compreendê-lo por situações, exigências, aspectos importantes da realidade contemporânea. Os meios de comunicação veiculam pessoas e povos materialmente muito distantes entre si. Além disso, a globalização econômica e financeira criou a interdependência entre todos os nossos interesses. Portanto, o que acontece em um país pode ter repercussões materiais imediatas em muitos outros.

Ainda: existem problemas que afetam a humanidade no seu conjunto. Basta pensar na questão ambiental e, em particular, a ecologia, o desenvolvimento e a alimentação, as problemáticas referentes ao patrimônio genético dos diversos grupos humanos.

Portanto, vivemos num mundo que se tornou realmente uma aldeia. A humanidade, hoje, vive como se fosse um pequeno grupo. Porém, ainda não conseguiu desenvolver

1 S. PALUMBIERI, "Homo planetarius": um homem novo para os tempos novos, em M. Mantovani e S. Thuruthiyil (aos cuidados de), Qual globalização? O homem planetário às portas da mundialidade, Roma 2000, p. 245. 
suficientemente um pensamento capaz de respeitar as diferenças, enquanto engloba a fundamental unidade. Os conceitos tradicionais de raça, religião, cultura, Estado, fragilizamse diante da complexidade da situação.

Pois bem, a fraternidade é a categoria de pensamento capaz de conjugar a unidade e a distinção a que anseia a humanidade contemporânea.

João Paulo II, falando ao Corpo Diplomático no dia 10 de janeiro de 2000, elegeu a fraternidade como o parâmetro de julgamento do século XX. Ele se perguntou: "O século XX foi também o século da fraternidade?".

A fraternidade, portanto, é o ideal dehoje.

Como suscitar a fraternidade?

Não faltam instrumentos para dar ao mundo uma fraternidade que possa gerar a unidade espiritual, garantia da unidade política, econômica, etc. Basta saber identificá-los. Um deles, cuja eficácia ainda não foi totalmente descoberta, foi o aparecimento, no mundo cristão, por exemplo, nas primeiras décadas do século XX, de dezenas de Movimentos e Comunidades eclesiais. São como muitas redes que unem povos, culturas e diferenças. São um sinal de que, a partir do nosso continente, o mundo poderia tornar-se uma "casa das nações", porque ele já o é, graças a essas realidades ${ }^{2}$, mesmo se de forma exígua.

São realidades que merecem grande e alta estima, pois não são efeitos de programações ou de projetos humanos, mas de carismas do Espírito Santo, que conhece, melhor do que qualquer homem e mulher da terra, os problemas do nosso planeta e deseja ajudar a resolvêlos. Pois bem, esses Movimentos, tendo sido fundados ou sendo compostos principalmente por leigos, veiculam um sincero e profundo interesse pela vida humana e exercem influência no campo civil, promovendo concretas realizações políticas, econômicas, etc.

Essas realidades vieram à tona há apenas três anos, quando a Igreja redescobriu a sua identidade e apresentou-se ao mundo constituída não só pelo seu aspecto institucional, como também pelo aspecto carismático, capaz de reconduzir o povo cristão, muitas vezes secularizado pelo contato com o mundo, ao radicalismo do Evangelho, sempre capaz de dar uma fisionomia nova à cidade terrena.

Esses Movimentos, cada um seguindo o próprio carisma, concretizam o amor de muitas formas. Muitos deles exprimem a força do Espírito na capacidade de dialogar profundamente com todos os homens e mulheres do nosso planeta.

Um deles é o Movimento dos Focolares que conta com milhões de membros, presentes em 182 países. Ele - junto a muitas outras organizações - introduz na nossa época a unidade e a fraternidade, onde quer que esteja.

2 Cf ALDO GIORDANO, no documentário sobre a evangelização dos Movimentos 
Vou dizer algo sobre o nosso Movimento, que conheço melhor, como um exemplo entre muitos.

O Movimento abriu, há quase meio século, quatro diálogos. O diálogo no âmbito da Igreja católica, que a ajuda a ser cada vez mais “comunhão", aquela comunhão que assegura a fraternidade e a paz. O diálogo ecumênico, na sua forma de "povo em diálogo". Este diálogo envolve, de modo muito vivaz, cristãos de 350 Igrejas, que compõem uma única "família cristã”, um prelúdio espiritual da única e futura Igreja. O diálogo com pessoas de outras religiões: muçulmanos, judeus, budistas, hindus, siques, etc., que hoje vivem em todo o lugar, devido aos fluxos migratórios. Diálogo possível, devido à "regra de ouro", que existe em todas as principais religiões da Terra. Ela diz: "Não faça aos outros o que não gostaria que fosse feito a você» (cf. Lc 6,31)". Essa "regra de ouro", em essência, é um convite a amar cada próximo. E, se nós amamos, porque somos cristãos, e os hindus, muçulmanos, judeus, também amam, nasce entre nós o amor recíproco e dali floresce a fraternidade.

Esse diálogo já estabeleceu, para o Movimento dos Focolares, uma fraternidade plena e sincera com um moderno Movimento budista de Tóquio, que conta com seis milhões de membros, e com outro Movimento muçulmano afro- americano de dois milhões de pessoas, o qual, pelo intercâmbio de dons, que se verifica no diálogo, abriu-nos as portas de 40 mesquitas nos Estados Unidos, onde podemos anunciar as nossas experiências de fé, por eles muito apreciadas.

Enfim, iniciamos também um diálogo com os irmãos que não possuem um referencial religioso, mas em cujo DNA está registrado o impulso de amar e são muitos.

Mas de onde provém esse sucesso, que oferece muita esperança, num único Movimento? O segredo do seu sucesso está numa nova linha de conduta, vivenciada por milhões de pessoas que, inspirando-se fundamentalmente em princípios cristãos

- sem negligenciar, aliás, evidenciando valores paralelos, presentes em outras crenças e culturas

- procura gerar no mundo a fraternidade, a paz e aunidade.

Trata-se da "espiritualidade da unidade", individual e comunitária a um só tempo, atual e moderna, apresentada hoje a toda a Igreja, para que todos a vivam, pelo Papa João Paulo II, sob o nome de "espiritualidade de comunhão".

Os pontos principais dessa espiritualidade são dois. 
O primeiro é a unidade, aquela unidade que Jesus pediu ao Pai antes de morrer: "Pai (...) que todos sejam uma coisa só" (cf Jo 17,11-21). Essa oração pede a unidade dos cristãos com Deus e entre eles e deve ser estendida a todas as pessoas, criando a fraternidade universal.

O segundo ponto fundamental é Jesus crucificado e abandonado quando gritou na cruz: "Meu Deus, meu Deus, por que me abandonaste?" (Mt 27,46 e Mc 15,34). Jesus, o Verbo de Deus, exatamente por ter-se feito homem, assumiu por solidariedade e amor a nós, todas as nossas culpas, as nossas divisões, os nossos sofrimentos; e por isso o Pai permitiu que ele sentisse aquele dolorosíssimo abandono.

Porém, com um esforço sobre-humano, Jesus superou essa tremenda provação e voltou a abandonar-se no Pai, dizendo: "Em tuas mãos, Pai, entrego o meu espírito" (Lc 23 , 46). Jesus abandonado tornou-se o modelo para todos aqueles que desejam recompor qualquer falta de unidade e sanar qualquer trauma.

Assim, amando Jesus abandonado, ajudamos a unir indivíduos e grupos, em todos os povos, trabalhando para a unidade da família humana.

O Movimento dos Focolares, embora seja fundamentalmente religioso, dedicou, desde 1948 e ao longo da sua história, uma atenção particular ao mundo político, até ver nascer no seu interior, em Nápoles, em 1996, o "Movimento político pela Unidade”, a serviço do mundo político. E hoje está difundindo-se e organizando- se em todo o planeta. Dele fazem parte: políticos, administradores, funcionários, estudiosos, estudantes e cidadãos, pessoas das diversas orientações políticas, de todas.

Não é um novo partido, mas o portador de uma cultura e de uma praxe políticas novas. Muda a metodologia da política. Mesmo permanecendo fiel às próprias e autênticas aspirações políticas, o político da unidade ama não só os políticos do seu partido, mas todos os outros políticos, procurando viver em comunhão com todos. Ele vive assim nas administrações municipais, nos partidos, nos diversos grupos de iniciativa cívica e política, nos parlamentos nacionais e regionais. Esse modo de viver a unidade é um fermento também entre os partidos, nas instituições, em cada âmbito da vida pública, nos relacionamentos entre Estados. O objetivo específico do Movimento político pela Unidade é: ajudar e ajudar-se a viver sempre a fraternidade; por ela, acreditar nos valores profundos, eternos do homem e só depois mobilizar-se na ação política.

Eis algumas ideias principais do Movimento político pela unidade.

Em primeiro lugar, para o político da unidade, a sua opção política é um ato de amor, com o qual ele responde a uma autêntica vocação, a um chamado pessoal. Ele quer satisfazer uma necessidade social, um problema da sua cidade, quer resolver os sofrimentos 
do seu povo, as exigências do seu tempo. Quem crê em Deus percebe que é Ele mesmo que o chama, através das circunstâncias; quem não crê, responde a uma exigência humana que encontra eco na sua consciência: mas é sempre por amor que ambos agem. Uns e outros, os políticos, encontram a sua casa no Movimento político pela Unidade.

Em segundo lugar, o político da unidade toma consciência de que a política é, na sua raiz, amor; e isso leva a compreender que também o outro, o adversário político, pode ter feito a própria escolha por amor. E isso exige que seja respeitada. O político da unidade deseja que também o seu adversário realize o projeto positivo de que é portador. Este projeto, se, por um lado, responde a um chamado, a uma verdadeira exigência, por outro, é parte integrante do bem comum que somente juntos pode-se construir. O político da unidade ama, portanto, não só os seus eleitores, mas também os adversários; não só o seu partido, mas também osoutros.

Eu disse isso no Parlamento Italiano e alguém afirmou: "Isso é meiodifícil!".

Outro aspecto da fraternidade na política é a capacidade de saber ouvir a todos, inclusive os adversários. Isso o leva a "fazer-se um" com todos e a abrir-se à realidade que o outro vive. O "fazer-se um" ajuda a superar os particularismos, revela aspectos das pessoas, da vida, da realidade, que ampliam o próprio horizonte político. O político, que aprende a "fazer-se um" com todos, torna-se mais capaz de compreender e de fazer propostas. O "fazer-se um” é o verdadeiro realismo político.

Ainda, o político da unidade não pode ficar passivo diante dos conflitos, muitas vezes ásperos, que escavam abismos entre os políticos e os cidadãos. Pelo contrário, ele dá o primeiro passo para se aproximar do outro, retomar a comunicação interrompida. Criar uma relação pessoal ali onde ela não existe ou onde sofreu uma interrupção, pode significar, por vezes, conseguir desbloquear o processo político em si. A fraternidade, ainda, encontra plena expressão no amor recíproco; fator de que a democracia, entendida retamente, precisa muito: amor entre os políticos e entre os políticos e os cidadãos. O político da unidade não se contenta em amar sozinho, mas procura suscitar no outro, aliado ou adversário, o amor, porque a política é relação, é projeto comum.

Uma última ideia-chave é que a pátria alheia deve ser amada como a própria; a maior dignidade para a humanidade seria aquela de não se sentir um conjunto de povos muitas vezes em luta, mas, graças ao amor recíproco, um único povo, enriquecido pelas diferenças de cada um e por isso mesmo guardião, na unidade, das diferentes identidades. É o que o Movimento procurou viver em momentos até dramáticos, por exemplo, através 
de gestos concretos de amizade e de paz atuados por povos de várias nações: gestos que tinham um profundo significado político.

Mas todos esses aspectos do amor na política, que realizam a fraternidade, exigem sacrifício. Quantas vezes a atividade política ensina o que é a solidão, a incompreensão inclusive por parte dos mais próximos!

Pois bem, é aqui que se recorre (também o político) a Jesus crucificado e abandonado, ressuscitado, graças ao amor do Pai; exatamente porque o político é aquele que abraça as divisões, as rupturas, as feridas da sua gente. É este o preço da fraternidade que é pedido ao político: preço altíssimo, mas altíssimo é também o prêmio. A fidelidade a toda prova fará do político um modelo, um ponto de referência para os seus concidadãos, orgulho de sua gente.

É esse tipo de políticos que o Movimento político pela Unidade deseja, com a ajuda de Deus, gerar, nutrir, apoiar e não é uma utopia, como vemos no exemplo de alguns dos nossos amigos que nos precederam no Céu: Joseph Lux, ex-vice-primeiro ministro da República Tcheca, que soube conquistar a admiração de colegas e adversários; ou Domenico Mangano, que foi vereador de Viterbo, fazendo um serviço constante aos seus concidadãos; ou Igino Giordani, cujo processo de canonização, aberto recentemente, está evidenciando como ele viveu não só as virtudes religiosas, mas também as virtudes civis: sinal de que é possível santificar-se não "apesar da política”, mas "através da política".

O Movimento político pela Unidade também está comprometido no plano do diálogo. Por exemplo, ele atuou no diálogo entre o governo e a oposição. Fizemos essas experiências nas administrações locais. Os membros do Movimento, que estão no governo, reconhecem as contribuições positivas da oposição e favorecem a sua função de controle. A oposição é feita por meio de uma crítica construtiva, que não tende a obstruir a ação do governo, mas a corrigi-la para melhorá-la. Em numerosíssimos casos, a unidade entre os nossos presentes no governo e na oposição favoreceu a busca da solução melhor para a comunidade, a qual só é garantida plenamente se ambos exercerem, da melhor forma, o seu respectivo papel. O Movimento político pela Unidade vê a humanidade como um único corpo, no qual todos os homens são irmãos. A humanidade é antes de tudo uma coisa só.

João Paulo II, falando aos nossos jovens, dizia:

\footnotetext{
Vocês querem sondar o caminho que é preciso percorrer para atingir um "mundo unido", conscientes de que esse "ideal" está escrevendo a "história". Realmente esta perspectiva parece emergir dos múltiplos sinais do nosso tempo: a perspectiva de um mundo unido ${ }^{3}$.
}

3 JOÃO PAULO II, Com o Movimento dos Focolares no Palácio dos Desportos, 31 de Março de 1990, em "La Traccia" 3 (1990), p. 323-324; 
O Papa disse isso antes do dia 11 de setembro. Agora o seu pensamento é certamente reforçado pelo gravíssimo perigo do terrorismo, que exige a unidade não só entre os homens e as mulheres do nosso planeta, mas entre os povos como tais e as forças que o governam.

Uma unidade sempre na diversidade, na liberdade, construída por pessoas e povos que são portadores de uma identidade própria e de uma cultura própria abertas e em diálogo com as outras.

E quando assim for, poderemos conhecer finalmente a paz.

Com efeito, enquanto encaminharmo-nos para essa meta, veremos realizarem-se outros sonhos de expoentes da nossa história. Como aquele de Martin Luther King:

Hoje sonhei que os homens tinham trocado as suas armas por arados e que a guerra deixava de ser objeto de estudo. (...) Com esta fé, nós seremos capazes de apressar o dia em que reinará a paz sobre a terra e a boa vontade para com todos os homens. Será um dia glorioso e as estrelas cantarão todas juntas, e os filhos de Deus gritarão de alegria. ${ }^{4}$

Que Deus e a nossa ação façam com que esse dia esteja próximo. Obrigada pela atenção que me foi dispensada.

4 Cit. 